\title{
Two Victorian corroborees: Meaning making in response to European intrusion ${ }^{1}$
}

\author{
Janice Newton
}

\section{Prologue}

Soon after separation of Port Phillip District from New South Wales, ${ }^{2}$ in 1851 and 1852, Guardian of Aborigines William Thomas witnessed and recorded new corroborees at Moonee Ponds, west of Melbourne, and on the northern bank of the Yarra. The first ceremony in 1851 was performed by the Wathawurrung from Leigh Creek, Buninyong and Bacchus Marsh and a few Bunwurrung from Melbourne. A leader, Ninggollobin, told Thomas that it was a new 'Sunday' or sacred dance sent down from the clouds by Veinnee (also spelt Vienie) to the Mt Emu Wathawurrung people.

Thomas described how, when he arrived, the participants shook hands with him heartily, then shook hands with the old leading man from the Buninyong people and with each other, their hands going up near their eyes, then down to their knees. To begin the dance, the leader lit a small fire, lit his pipe majestically, then he held

\footnotetext{
1 I would like to thank Dr Marguerita Stephens for the inspiration for this article, which has been developed from a paper delivered at the Annual Australian History Conference, Federation University, Ballarat, July 2016. The suggestions of Professor Ian Clark and journal reviewers have also been most valuable. Note: The citations from Thomas in this paper are based on Marguerita Stephens' 2014 transcriptions of William Thomas' journals as well as some emailed personal communication from Stephens regarding material that was found too late to be included in the transcription volumes.

2 In Victoria, Aboriginal people and the Native Police were part of the 1850 celebrations in which gifts of food and blankets were given. Curthoys 2012: 246.
} 
a Bible at full height, kept open by his hand, while the 23 male dancers on the other side of the fire danced in a crescent formation for 45 minutes. They held small boughs in their right hand and kept their gaze steadfastly on the Bible. ${ }^{3}$

This Bible, along with other two other Bibles, two testaments and four prayer books, had appeared apparently miraculously to the Mt Emu people, laid out individually on pocket handkerchiefs, alongside sticks of tobacco, at a camp. The Mt Emu Clever Men, whom Thomas referred to as 'Doctors', talked all night and came to the conclusion that the books and items had come from the clouds:

One 'Doctor' took the book to a Settler who stated that the book came down from heaven to make men good happy \& love one another, shake hands like messmates (friends), so the Doctors had established this dance Vienie, \& were sending the dance to all parts to establish unity among all tribes. ${ }^{4}$

The latter March 1852 ceremony on the northern banks of the Yarra near Melbourne was described by Thomas as a 'Glee Day Dance Flags Flying \&c.'. ${ }^{5}$ This ceremony made use of unusually large -5 feet 8 inches high - bark effigies. Although such bark items were not unknown in Victoria, ${ }^{6}$ these also incorporated trimmed, tall gum sapling 'flag poles' with up to five handkerchiefs of gay colours joined together mimicking flags or bunting at each end. Thomas's annotated diagram explains in Aboriginal English, from an informant, that King Paget of Mt Cole tribe: ${ }^{7}$

a very good man 'Go up above the sky and bring ... down Book \& Corrobery Kulbul(i?)'. 'Kunnuwarren Queen always go up to school. ... Tununderboollook Tribe beyond Mt Cole, long long way (NW?). 'All are buried when die and the Moorup (spirit/soul) of good man come thro' the fire. You got it nebbo (?) what me say. ${ }^{8}$

Further annotations state that two males and two females led the dance. Bark figures were 3 feet 2 inches high, and there was 'a $1 / 2$ man (figure) above 20 inches on the donkey'?

\footnotetext{
3 The choreographic sketch by Thomas of 'Dances, Effigys \&c Belonging to "Veinie"' is dated at 1852 by Byrt 2004: 168, 243; Stephens, pers. comm., 2015. Fn in State Library of Victoria (SLV) MS14624 Series 111 Book of letters IN \& OUT 1850-52, attached to entry 14 January 1851. Marguerita Stephens, pers. comm., 2017 states that the original caption given in Stephens 2014 vol. 2: 523 was mistranscribed as 'Dances, Effigys \&c Belonging to $\underline{\mathrm{Vi}[\mathrm{c}] \text { toria'. }}$.

4 Marguerita Stephens, pers. comm., 2015. Fn in SLV MS14624.

5 Stephens 2014, vol. 2: 522 [Mitchell Library MS (ML)214 Reel(R)26frame(f)245], 30 March 1852. Bracketed archive reference as per Stephens 2014; ML Ms 214 box and item numbers are identified in that text at the beginning of each year.

6 Willis 2007.

$7 \quad$ Mt Cole clan leaders in 1841 were Titgomurnin (Big One Billy) and Pegetnowerrer, probably the Paget listed as King of Mt Cole in 1850s. Clark 1990: 112; Ian Clark, pers. comm., 2015.

8 Stephens 2014, vol. 2: 523, fn 236.

9 Stephens 2014, vol. 2: 523, fn 236. 'Pageb' altered to 'Paget', and tribal affiliation to Djabwurrung on advice from Ian Clark, pers. comm., 2015.
} 


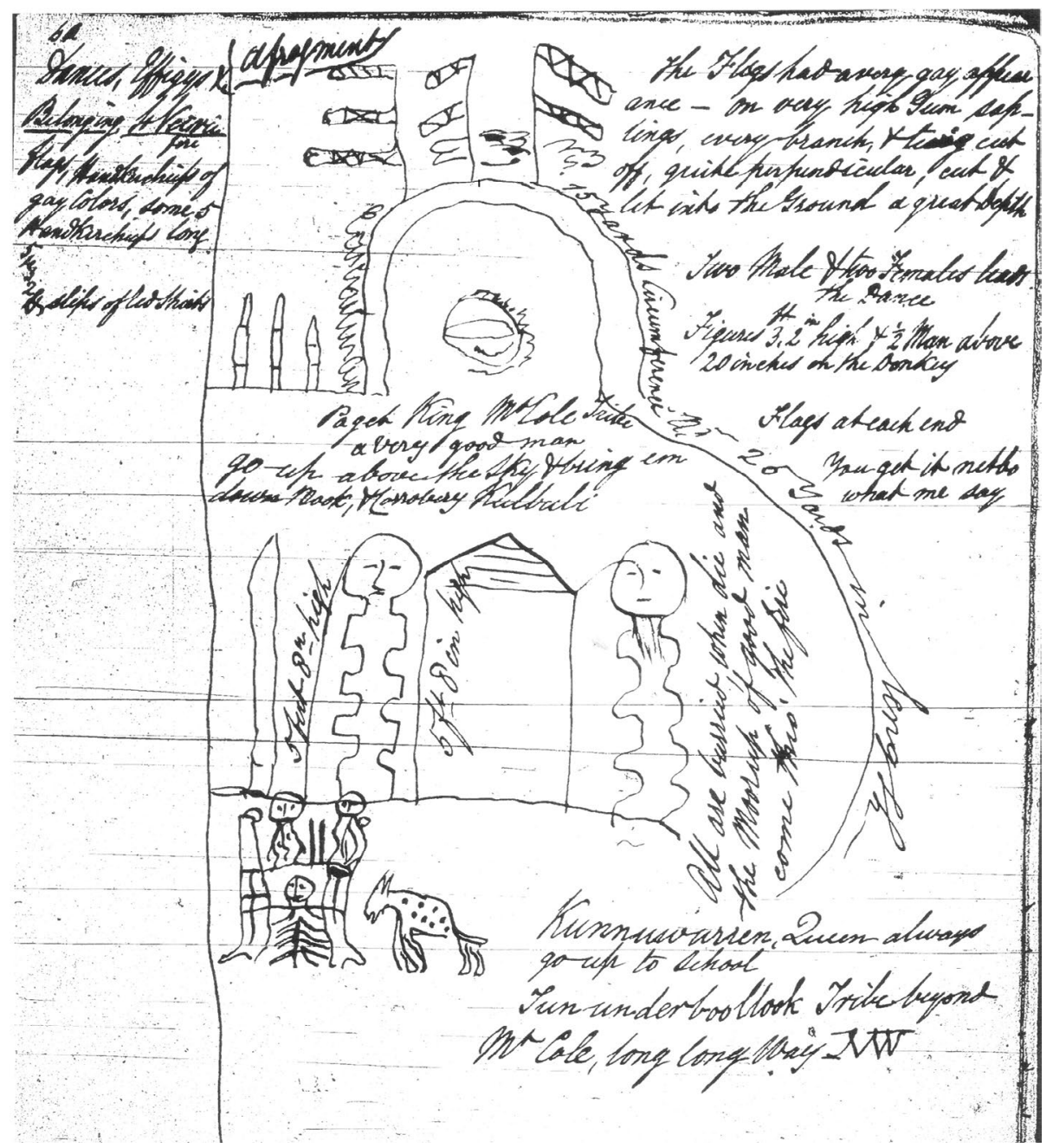

Figure 1: Diagram by William Thomas of Corroboree Layout c. 1852. 'Dances, Effigys \&c Belonging to "Veinie".'

Source: Stephens 2014, vol. 2: 523. The sketch is listed by Byrt 2004: 243 and sourced to ML 214/3 frame 41.

\section{'Minutiae of action and context': Re-examining syncretism}

Such corroborees have been recently described as evidence of syncretism between particular Indigenous traditions and Christianity. ${ }^{10}$ In order to extend understanding of the Indigenous response to Christianity and construction of meaning in

10 Stephens 2014, vol. 2: 523, fn 246; Ripon et al. 2015; cf. Cahir and Clark 2010. 
frontier contact zones in settler colonial societies, I wish to critique and tease out an oversimplified notion of syncretism. Religious syncretism refers commonly to the union, blending or reconciliation of two or more religious belief systems into a new system. To think more critically about this, I consider the value of the theoretical ideas of Homi Bhabha and Andrew Lattas on mimicry and demonstrate the substantial scope for change and creative action in a culture that was for many years represented as changeless, or locked into ancestral lore. The evidence from the two corroborees and the microhistorical context, as reported by William Thomas, exhibit strong parallels and some points of difference with religious movements of renewal in other, comparable contact zones.

In the absence of any extant detailed Indigenous explanation, much of the meaning of the corroborees remains hidden and esoteric. A starting point for future comparisons and richer analysis of corroborees and rituals from south-eastern Australia is to look at specific nodes of performed, embodied patterns of ritual behaviour and paraphernalia. Items of celebratory and ceremonial material culture are 'entangled objects', ${ }^{11}$ which, like the performed behaviours, have multiple layers of meaning in the European and Aboriginal worlds and have been appropriated from or adapted to Western culture. ${ }^{12}$ Evidence on pipe smoking, handkerchief use, handshakes, the written word and Bibles in particular offer a fertile way to consider key messages and rituals of friendship, peace and meaning making in the contact zone.

This article aims to build on insights of current historiography of the contact zone by a close reading of particular episodes, a focus on the 'minutiae of action and context', in order to attain 'double vision', and appreciation of 'mutual attempts at interpretation between the Indigenous and Western settlers'. ${ }^{13}$

Lacking direct Indigenous sources, I do this for the most part through a detailed examination of Thomas's journals. Thomas may have been surprised at this Christian turn in the Victorian corroborees, but his own journals give many clues about the deep thinking occurring among the Port Phillip Aboriginal people during the 1840s and the build-up to the corroborees witnessed in 1851-52.

11 Nicholas Thomas disputes essentialist claims about the uses of material objects in colonial situations and about the operation of gift or communal economies. When capitalist trade enters an indigenous economy, objects become 'entangled', creatively 're-contextualised' and not always what they were 'made to be'. Thomas 1991: 2-5.

12 Penelope Edmonds has recently published a detailed historical analysis of symbolic historical compacts, accords and covenants in contact zones of settler societies. She argues that the embodied behaviours involved in the past, and in present reconciliatory performances, offer a lens to heightened insight of settler-Indigenous experience. In North America peace pipes, wampum beaded belts and covenant chains were involved in rituals of mutual invention, thus enabling a 'kind of peace'. Edmonds 2016: 24, 40.

13 Jebens 2004: 11; Swain and Rose 1988: 5; Parker and Rodseth 2005; Russell 2001; Shellam 2009: 21; Edmonds 2016. See also Rowse 1987 on the supernatural and Aboriginal sense-making on the north-western frontier. 
Religious responses to frontier experience generally and ideas about mimicry are discussed as a basis for comparison. The scope of the change that confronted Victorian Aboriginal people after 1835, and the experiences of Thomas in his efforts to bring Christianity, also serve as important background material to an understanding of the two corroborees. The detailed explication, in keeping with approaches that acknowledge Indigenous people as legitimate actors, ${ }^{14}$ focuses, as stated, on Aboriginal creative adaptation and 'mimicry' of specific items of European material culture and everyday behavioural rites. ${ }^{15}$ The article concludes with an examination of Aboriginal responses to Thomas's teachings on Christianity, evidence of innovative creativity in corroborees and an overview of the value of looking at behavioural rites and specific objects as nodes of meaning making in a situation of culture contact.

\section{Religious movements in the contact zone}

There are some pertinent similarities between aspects of the 1851-52 corroborees and religious responses to colonialism in the Melanesian islands north of Australia and Prophet movements in New Zealand. In the Paliau Movement in Manus Island and Vailala Madness of the Papua New Guinean Gulf, the villagers imitated European manners and customs in various ways; for example, sitting at tables on chairs, wearing Western clothes, handshaking, drilling their own police force. ${ }^{16}$ This mimicking of behavioural features of European life was usually seen as ill-founded, irrational copying. While Margaret Mead saw the Manus Island Paliau Movement as a progressive movement of radical transformation towards the brotherhood of man and peace, ${ }^{17}$ others emphasised the significance of the Melanesian worldview and how they understood the cosmic order. ${ }^{18}$ Melanesians 'gave an autochthonous form to the civilizing processes that were transforming them'. ${ }^{19}$

From 1850 to the early 1900s, after huge losses of land, which was their means of spiritual and economic subsistence, and a series of wars (1845-72), the New Zealand Māori feared extinction. ${ }^{20}$ Differing from Australia in its indigenous structure of settled villages, political hierarchies and a single language, New Zealand by the 1840 s had missionary and Māori quickly learning each other's languages. Conversions to Christianity proceeded apace with Māoris astounding missionaries with their memorisation of scriptures and their detailed understanding of biblical stories. They incorporated biblical symbols and paradigms into their whakapapa

14 Russell 2008.

15 Russell 2008. See also Broome 2010.

16 Hogbin 1958: 208-09; Dawn Ryan, pers. comm., 1976-78.

17 Mead 1956: 194, 200, 210.

18 Lawrence 1964: 30-31, 222, 226, 233.

19 Lattas 1998: xxi, xxxi.

20 Rosenfeld 1999: 3. 
genealogy cultural 'bank' and, as the dramatic land loss occasioned by colonialism became painfully apparent, they began sophisticated reinterpretations of biblical narratives. The religious/political prophet movements, for example, aimed to have a Māori King sharing power with the British Queen, aligned the Māori with Israelite ancestors and called upon ' $\operatorname{god}(\mathrm{s})$ to recreate their world'. ${ }^{21}$ European and Christian biblical renewal myths 'were often blended with indigenous myths of return', ${ }^{22}$ and prophesies were made about a Promised Land and a time of peace. ${ }^{23}$ The salient feature of the syncretism in these movements was not the mix of tradition and new Christianity, but the autochthonous attempt to restore the sacred by retaining power over the land. ${ }^{24}$

Scholars have generally claimed that Aboriginal Australia did not experience millenarian movements like the New Zealand Prophet movements or the cargo cults of Papua New Guinea, ${ }^{25}$ but there is a small body of work that counters this conclusion. Swain agrees with Burridge that, from first contact, millenarian activities were possible. He argues that south-eastern Australian Aborigines clearly 'articulated the likelihood of an imminent end to their world' and expressed anti-white sentiment in a range of ritual activities. ${ }^{26}$ Similarly, millenarian type movements, some with a material goods focus, have also been reported in the north and north-west of Australia in a later frontier period. ${ }^{27}$ Informative comparisons can also be drawn with the American Ghost Dance Movement. Political opposition and spiritual excitement go hand in hand for much of this history of mimicry and creative religious response to the trauma of colonialism. The Ghost Dance gained its initial impetus from a Paiute prophet called Wovoka, but spiritual opposition, prophesy and reaction to the colonial yoke had at least a 400 -year history. ${ }^{28}$ Changes and vitality in Native American religious beliefs and practices before and after colonialism belie any notion of a romanticised, static 'precontact' society. Native American culture incorporated notions of destructions followed by regeneration and renewal, visions, a messiah returning to restore an 'original happy condition', prophesy and heralding signs. ${ }^{29} \mathrm{New}$ theology and ritual borrowed from Christianity but held onto key features of native traditions. ${ }^{30}$

\footnotetext{
21 Rosenfeld 1999: 3, 5, 7.

22 Rosenfeld 1999: 5.

23 Rosenfeld 1999: 96.

24 Rosenfeld 1999: 70.

25 Berndt 1962; Tonkinson 2004.

26 Swain 1993: 133. See also Koepping 1988: 398, 400.

27 Borsboom 1992; Kolig 1988; Swain and Rose 1988; Petri and Petri-Odeman 1988: 393; Bos 1988; Koepping 1988. See also Calley 1965: 52.

28 Mooney 1973 [1896]: 658-61; Irwin 2008: 19, 21-33, 40.

29 Irwin 2008: 3-5; Mooney 1973 [1896]: 658-61. Irwin stated that 'native epistemology fully supports visionary experiences as central to the primary source of religious knowledge and empowerment'. Irwin 2008: 14. 30 Irwin 2008: 133.
} 
New prophet movements among the Native Americans in the 1870s and 1880s incorporated into their rituals and dances embodied practices such as marching in single file, shaking hands and reciting chants from writings and objects resembling Christian icons, and drew on Christian ideas. Smohalla and the John Slocum Shakers made use of Catholic paraphernalia and Western symbols, including flags, signs of the cross, a book containing mysterious characters and enthusiastic handshaking. ${ }^{31}$

The Ghost Dance was developed after a Paiute, Wovoka, experienced a vision in 1887. This vision prophesised that living and dead Native Americans would 'be reunited upon a regenerated earth, to live a life of aboriginal happiness, forever free of death, disease and misery', ${ }^{32}$ and also be free of the white population, who would be removed by some natural disaster. ${ }^{33}$

The strong Sioux prairie tribe took on the ritual, incorporating a ghost shirt and dress painted with symbols meant to ward off bullets. They ignored a government ban on the movement; troops overreacted, culminating in the 1890 Battle of Wounded Knee, where more than 300 dancers and fleeing women and children were massacred. ${ }^{34}$

Irwin rejects explanatory models of this religious movement that go no further than notions of misguided copying and syncretism. It is important to see the engaged, visionary creativity as well as the syncreticism; to recognise the continued vitality of indigenous practices and beliefs; and to use an ethnotheology that delves into the ontological depths of indigenous thought. ${ }^{35}$ The dance infused and incorporated ideas and paraphernalia from Christianity onto a traditional indigenous framework. The religious rituals were sites for transformation, subversion and experimental practice. 'Rather than turning to Christianity, ghost dancers contended with it in order to turn its powers to their advantage. ${ }^{36}$ Concepts of renewal and moral rejuvenation were indigenous ones.

Compared with the detailed testimonies available for the Ghost Dance movement and in the near absence of Indigenous writings and explanations in south-eastern Australia, attaining ontological depth in the latter context is a formidable task. Detailed examination of the minutia of ritual life is aided by a consideration of the theoretical ideas on mimesis in a colonial situation.

31 Mooney 1973 [1896]: 719-29, 746-62; Irwin 2008: 288, 298.

32 Mooney 1973 [1896]: 777.

33 Ostler 2004: 247-50.

34 Irwin 2008: 314.

35 Irwin 2008: 7-9.

36 Irwin 2008: 255. 


\section{Mimesis}

The concepts and theories of Homi Bhabha, often used to analyse and unpack contemporary literature and global situations of refugees and global movements of people, have also been shown to be fertile for understanding of past situations in border and frontier situations. The postcolonial historian of borderlands and frontier contact zones is enriched by sensitivity to cultural hybridities, the importance of the 'migrant's double vision', the rites of extraterritorial and cross-cultural initiation and the often hidden indigenous narratives internal to national identities. ${ }^{37} \mathrm{I}$ wish to attempt to think about mimicry from the point of view of indigenous people confronted with a colonial power encouraging and modelling behaviours and thoughts while their traditional political and cultural autonomy is almost flushed away and access to the new power of the colonist remains elusive.

Bhabha discusses the significance of mimicry in a colonial situation. It underpins a desire for a 'reformed recognisable Other', who nonetheless is never quite the same as the colonial model. This 'not quite the same' creates uncertainty, ambivalence and partial representation. Mimicry, within its double vision, holds within it the seeds of menace that can disrupt colonial authority, producing a 'partial vision of the colonizer's presence' ${ }^{38}$ Mimicry is like camouflage and is a 'form of resemblance' but it carries a threat through 'conflictual, fantastic, discriminatory "identity effects" in the play of an elusive power'. ${ }^{39}$ The founding objects of the Western world become 'erratic, eccentric, accidently' 'found objects' of the colonial discourse. Objects may appear in a different guise, thought of differently. The Holy Bible, for example, can lose its 'representational authority', become 'strangely dismembered' and be used in mundane and non-sacred, 'profane' ways. ${ }^{40}$

Andrew Lattas develops the concept of copying or 'mimesis', providing fruitful lines of thought for contact zone history. He argues that mimesis is a 'creative way of thinking about and responding to Western processes of social change'. The people 'exploit chance resemblances and associations to create mimetic channels and magical gateways between (their own culture) and Western culture'. The 'miming often seems odd and out of context' and seemed abnormal and lacking rationality to Westerners. The people try to create a new sense of self by reworking some of the 'embodied practices of the self'; for example, 'everyday gestures'. Religious ritual is a technology to 'maintain the cosmic order'. More importantly, Lattas advises that it is 'inadequate to gloss such (copying) processes as "syncretism" or adjustment

37 Bhabha 1994: 2, 5, 6, 9.

38 Bhabha 1994: 86-87.

39 Bhabha 1994: 90.

40 Bhabha 1994: 91. 
movements' ${ }^{41}$ Intersections and misreadings both 'embrace and evade incorporation into Western institutions'. When the particularities of the intersections between indigenous and Western cultures are studied, they are 'never completely disordered or haphazard'. Misreadings are formed into coherent systems of ideas that feed off dominant culture. Accidental meanings can drip from the dominant culture and be used, with tradition, to contribute to a new alternative. ${ }^{42}$

Supernatural interpretations of the new European order are often made because organised missions are a powerful force and provide a basis for the 'myths of the "secret" part of Christian knowledge hidden by the whites'. ${ }^{43}$ In many traditional societies, religion is a technology to 'maintain the cosmic order'. 'Elaborate myths and intensive rituals' are seen as essential for continuity, so even in new cults there are former conservative attitudes and concepts. Work towards the future is both secular and ritual. ${ }^{44}$ What initially seems, to a Westerner, weird and random mimicry, warrants double vision, deeper thought and analysis. The historical context of the 15 years prior to the corroborees discussed assist in this task.

\section{Shocking and inexplicable change}

The first years of permanent settler colonialism in Melbourne were truly shocking in impact for the Indigenous people. Stephens calls it 'a time of unprecedented and unequalled turmoil and upheaval as a whole world of meaning and means came under challenge and all but disintegrated'. ${ }^{45}$ Lethal new diseases brought on massive loss of life and infertility, and would not respond to traditional healing methods. Most likely this provoked increasing revenge killings for deaths attributed to sorcery. Within a few years, the Victorian tribes experienced a rapid, escalating eviction from their land and from natural resources such as forests and water. Aggression against the Europeans met armed and legal reprisals of greater scope and brutality than most knew. They came to know the horror of gaol confinement and public hangings. Aboriginal freedom of movement was severely curtailed as they were prohibited access to their traditional place for meeting near Melbourne. They saw the development of townships, and rapidly developed strong desires for new addictive and strongly reinforcing substances like tobacco, alcohol, sugar and tea.

\footnotetext{
41 Religious responses to contact with millenarian elements include the so-called 1950s Adjustment Movement described by Ronald Berndt among the Elcho Islanders and a later revival called the 'Black Crusade', and the Jesus cult in Western Australia in the 1960s. Berndt 1962; McIntosh 2004; Borsboom 1992: 14, 17; Bos 1988: 426, 433. 42 Lattas 1998: xxiii-xxv, xxxiii, xlii.

43 Worsley 1957: 248-49.

44 Lawrence 1964: 30-31, 222, 226, 233.

45 Stephens 2014, vol. 1: iv. The circumstances leading up to the Ghost Dance Movement in North America demonstrate many parallels: famine, violence, introduced disease, tremendous loss of life, removal from land and a gold rush. Ostler 2004: 266; Irwin 2008: 288.
} 
Victorian Aborigines quickly took up some new economic options. Gaining almost immediate superiority in use of the gun for hunting, many Aboriginal men entered exchange contracts with whites to hunt for them. A few travelled interstate, or even overseas, with white explorers or adventurers. Others agreed to join the Native Police, embraced horse riding, the uniform and the risk of travelling into enemy territories. ${ }^{46}$

Evidence of rupturing worldview and a society severely challenged by the invasion can be seen in the increased mobility, frequent gatherings in Melbourne, the meetings, discussions and dances. ${ }^{47}$ These ritual attempts to formulate a new future demonstrate creative responses to change, often within traditionally religious frameworks, and reflect similar circumstances for indigenous religious movements within other settler colonial contexts. In the Victorian (Port Phillip) context, key personalities interacting with the Aboriginal people were the Protector of Aborigines George Augustus Robertson and his Assistant William Thomas, whose journals are the basis for this discussion.

\section{William Thomas: Assistant Protector and Guardian (1839-52)}

William Thomas, born in Westminster of Welsh parents, was an 'unassuming Wesleyan schoolmaster of middle years and moderate income' when appointed Assistant Protector of Aborigines for the Port Phillip colony in $1837 .{ }^{48} \mathrm{He}$ was encouraged to apply by a prominent Whig, the Countess of Ilchester, following his interest in the British Select Committee of Enquiry on Aborigines (British Colonies). Thomas began his appointment and his journals in January 1839, after presenting himself to the Superintendent of Port Phillip, Captain Lonsdale. He continued to record his life and work until months before his death in 1867, aged $74 .{ }^{49}$ Protector and Guardian, he also became official visitor to reserves and depots following the 1860 creation of the Board of Protection..$^{50}$ Some recent scholars have contested the widely held view (personally promulgated in his journals) ${ }^{51}$ of Thomas as a friend to the Aborigines, known for 'his goodness of heart' and cited as 'more successful than any other first generation settler in attempting to comprehend and sustain Aboriginal society'. ${ }^{52}$ His journals are a useful source for Aboriginal voices as

46 Stephens 2014, vol. 1; Christie 1979; Broome 2005; Cahir 2012.

47 Stephens 2014, vol. 1; Standfield 2012.

48 Stephens 2014, vol. 1: iii.

49 Stephens 2014, vol. 1: iii-iv; Mulvaney 1967.

50 Stephens 2014, vol. 1: iii-iv; Reed 2004.

51 Reed 2004.

52 Mulvaney 1967. 
he recorded many conversations verbatim. ${ }^{53}$ Like all Protectors of the time, walking a shadowy line between advocating for 'his' Aboriginal charges and supporting the colonial project, ${ }^{54}$ Thomas was hampered by his whiteness and Eurocentric eyes that may well have led to unhelpful policies. ${ }^{55}$

From the outset, Thomas worked extremely hard to learn Aboriginal languages with a view to Christian proselytisation, and he was soon giving sermons partly in native tongue. That the Aboriginal word 'Bunjil/Punjil' of the preeminent creator eagle/ spirit was used for the Christian God with 'Father' added $^{56}$ gave scope for slippage in meanings. ${ }^{57}$ In the early years, Thomas was adamant about keeping the Sabbath, doing his utmost to prevent work and corroborees on that day. He attributed his own and others' illness and bad luck to sin and failure to keep the Sabbath. ${ }^{58}$

Thomas swung between hope and disillusion in relation to his efforts to spread and model Christianity. On balance, he was despondent and very pessimistic about his achievements, often lamenting the need to offer bread and rations in order to get any interest from his Aboriginal people. ${ }^{59}$ For example, in August 1840, he noted: 'A man had need ... if he wishes to be heard, hold a Bible in one hand \& a long spear with loaves ... run thro' on the other'. ${ }^{60}$

There were brighter moments when the children from the school learned to sing hymns and repeat catechisms, and when Thomas's congregations were large, particularly attentive, appeared interested and asked questions. Thomas wrote in May 1843, 'I do not know that I have ever had a more comfortable (Sunday) with the blacks', but ' $[\mathrm{u}]$ nhappily such Seasons are of rare occurrence' ${ }^{61}$ Like Sir George Grey in the South Australian settlement, who saw Europeanisation in bodily habits as an essential part of the civilising Christian mission, Thomas was gratified when

\footnotetext{
53 Standfield 2012: 3.

54 Nettlebeck 2017.

55 Reed 2004. See also Pascoe 2014; Stephens 2014, vol. 1: i-ii. According to Pascoe (2014: ii), Thomas was 'probably the best man any Aboriginal was likely to meet in Melbourne in 1839' but he never wavered 'in his presumption of the superiority of his culture and his spiritual beliefs'.

56 Stephens 2014, vol. 2: 240 [ML214 R3f404-6], 17 April 1847.

57 Swain (1993: 114-58) argues that the notion of 'Bunjil the all father God' was a result of Christian assimilation.

58 Fels 2011; Stephens 2014, vol. 1: 193 [ML214 Rlf167], 2 August 1840; 240 [ML MSS 214 R2f192], 22 November 1840; 407 [ML214 R2f373], 14 November 1841; 506 [SLV MS14624 Series 1 William Thomas Journal], 19 March 1843; Stephens 2014, vol. 2: 211 [ML214 R3f395], 13 December 1846; 246 [ML214 R3f437], 2 May 1847; 413 [ML214 R3f617], 28 October 1849.

59 Stephens 2014, vol. 1: 323 [ML214 R2f306], 4 July 1841; Stephens 2014, vol. 2: 117 [ML214 R3f291], 3 August 1845; 285-86 [ML214 R3f476], 31 December 1847. See also Stephens 2014, vol. 2: 336 [ML214 R3f537], 21 October 1848.

60 Stephens 2014, vol. 1: 195 [ML214 Rlf170], 9 August 1840. See also Stephens 2014, vol. 1: 413 [ML214 R2f379], 12 December 1841; 423 [ML214 R2f385], 9 January 1842; Stephens 2014, vol. 2: 180 [ML214 R3f360], 12 June 1846.

61 Stephens 2014, vol. 1: 516 [SLV MS14624 Series 1].
} 
the Aboriginal people came to Sunday service in European clothes, well-washed, shaved and with hair combed, and some Aboriginal leading men began to take up this standard for themselves. ${ }^{62}$

Thomas's weekly sermons responded to what was going on around him. As the vices of Melbourne, drunkenness and subsequent imprisonment took their toll, and there was an escalation of revenge killings after sudden deaths, his sermons reflected this. Otherwise, his sermons reflected standard Protestant Christian texts, with perhaps a small focus on God's omnipotence, ${ }^{63} \operatorname{love}^{64}$ and punishment in hell. ${ }^{65}$ Of particular relevance to the argument here were the sermons, for example in 1846 , on the ignorance of man without knowledge of God's book. ${ }^{66}$ In early 1851 , Thomas also addressed a Brighton encampment on 'the comforts of civilized life brought about by meditating on God's word his character $\& c^{\prime} .{ }^{67}$

Thomas's ethnographic insights were clustered in certain areas. He developed a strong interest, understanding and, sometimes, respect for aspects of traditional Aboriginal life. He noted, in detail, healing methods (on occasion submitting to them) and explanation for sickness and death. He had an astute understanding of the political system of authority and decision-making and the legal system of judgment and punishment. He had a strong sense of the significance of spatial ordering when tribes met for meetings. He was quite 'modern' in his cultural relativism on these matters, but on other matters more blinkered. Thomas made very little mention of creation stories and no mention of kinship organisation. Neither was he 'ever willingly admitted to the higher levels of secret and sacred ceremony'. ${ }^{68}$ In general, however, his journals and letters are a very rich repository of knowledge and perceptions of the frontier situation in early Melbourne and allow us to look more closely at the Indigenous use of certain cultural artefacts. I consider the pipe, the handkerchief, the written word - in particular, the Bible - and the handshake as significant performative symbols in strategic responses to colonial invasion and Christian evangelism.

62 Stephens 2014, vol. 1: 165 [ML214 Rlf142], 17 May 1840; Scrimgeour 2006; Stephens 2014, vol. 1: 240 [ML214 R2f192], 22 November 1840; 358 [ML214 R2f334], 22 August 1841; 433 [ML214 R2f393], 6 March 1842.

63 Stephens 2014, vol. 1: 122 [ML214 R2f32], 10 January 1840; Stephens 2014, vol. 2: 442 [ML214 R4f29], 9 June 1850.

64 Stephens 2014, vol. 1: 193 [ML214 Rlf167], 2 August 1840; Stephens 2014, vol. 2: 80 [ML214 R3f254], 5 January 1845.

65 Stephens 2014, vol. 2: 51 [ML214 R3f232], 20 \& 27 October 1844; 89 [ML214 R3f263], 23 February 1845.

66 Stephens 2014, vol. 2: 147 [ML214 R3f321], 4 January 1846; 208 [ML214 R3f392], 22 November 1846.

67 Stephens 2014, vol. 2: 474 [ML214 R4f79], 5 January 1851.

68 Stephens 2014, vol. 1: v. 


\section{The pipe}

Tobacco was often presented in early encounters as 'a token of goodwill and conciliation', ${ }^{69}$ and Aboriginal people quickly took up the ubiquitous custom of smoking using a pipe. ${ }^{70}$ Tobacco became widely sought after by men, women and children, highly valued in exchange for goods and labour and for trade. ${ }^{71}$ The significance of this innovation becomes apparent in three entries by Thomas.

In 1841, an old man, Tottoy, considered God's creation on earth and said, God made 'the Main Stars, sun, water, me' and the tobacco pipe. ${ }^{72}$ Thomas also noted that an Aboriginal 'greeting gesture' (one that could not be refused) was to put one's pipe in the mouth of the other. When a boy, Jimme, was released from gaol to the mission and led to his brother, 'his brother run to him and shoved his pipe in his mouth'. ${ }^{73}$

On another occasion, Thomas attempted to reject this overture and risked the fragile friendliness of an encounter with a stranger.

Among Blacks an exchange is decided friendship and fidelity. I remember once raising the ire of some strange Blacks I had never seen before in refusing to take my pipe out of my mouth $\&$ put it in his $\&$ my receiving his pipe. ${ }^{74}$

The opening of an 1851 ceremony with the lighting of a pipe thus can be read, at least partially, as an invitation to friendship in a new colonised context. The Aboriginal pipe-swapping greeting demonstrates how new items can be modified and used in different ways; a mimicry, but not quite the same. In this case, the meaning of the differing pipe lighting and sharing appeared to have enhanced the European meaning, to connote 'friendship and fidelity', as noted by Thomas.

\section{The handkerchief}

Handkerchiefs featured in both of the unusual corroborees described by Thomas. They held the miraculous gifts of Bibles and tobacco and, sewn together, they were remade into symbols of celebratory bunting. (European needles and thread were quickly taken up by Aboriginal Victorians. $)^{75}$ By the mid-nineteenth century, the

69 Cancer Council of Australia 2016

70 In much of Australia prior to British colonisation, the Aboriginal people were accustomed to chewing tobaccolike substances (most commonly pituri) and in the far north they used wooden, bone and shell smoking pipes. Courtney and McNiven 1998: 51; Brady 2002; Watson et al. 1983; Cancer Council of Australia 2016.

71 Cancer Council of Australia 2016.

72 Stephens 2014, vol. 1: 320-21 [ML214 R2f303/4], 27 June 1841.

73 Stephens 2014, vol. 2: 259 [ML214 R3f451], 4 August 1847.

74 Stephens 2014, vol. 2: 265 [ML214 R3f457], 15 September 1847.

75 Stephens 2014, vol. 1: 181 [ML214 R1f152], 30 June 1840; 362 [ML214 R2f336], 23 August 1841. 
handkerchief was already a multi-use and polysemic item of European culture. The hemmed square of thin fabric was kept in the purse or pocket and, since the sixteenth century at least, used for the wiping of the face, the hands or blowing of nose, as an impromptu method of carrying small items, as a head covering or bandage, clothing patch, footwear repair and so on. Depending on the type of fabric and decoration, it could be symbolic of social class and much more. From the late eighteenth century, white handkerchiefs were waved to demonstrate approval at public rallies, often in a colonial context. Handkerchiefs could also be decorated with flags and slogans to demonstrate political loyalties. ${ }^{76}$

Although there have been some suggestions that handkerchiefs were primarily a colonial and mission imposition bringing bodily cleanliness and order to Indigenous subjects, ${ }^{77}$ like the Europeans, Aboriginal people often desired handkerchiefs as head coverings, small containers and self-decoration for respect and esteem..$^{78}$ On the Australian colonial frontier, handkerchiefs have been present at key political moments and in relation to key political figures. Bennelong asked for pocket handkerchiefs, ${ }^{79}$ Batman gave 200 in his treaty exchange, ${ }^{80}$ explorers used them for exchanges ${ }^{81}$ and Yarra leader Billibellary, anticipating his imminent death, cried into his pocket handkerchief. ${ }^{82}$

By 1847 , the handkerchief had become a valuable used for Indigenous ceremonial exchange. In a ceremony establishing or re-establishing mutual friendship, the Devils River (Mansfield) people gave the Yarra people spears and a koogra (possum skin cloak) and received five koogra and bundles of pocket handkerchiefs, sashes and new European articles in exchange. ${ }^{83}$

Handkerchiefs thus had use value as well as status and symbolic value for Aboriginal people in frontier situations. In the Mt Cole-derived corroboree, handkerchiefs were used to construct bunting and thus acted as a form of mimesis of European spectacle, celebration or show. Flags were commonly flown outside early goldfield shops and bunting was likely a part of celebrations in Melbourne and beyond. They also featured in Aboriginal artist Tommy McRae's drawings of a dance performed by Wathawurrung Aborigines, with William Buckley, in relation to a sailing ship. ${ }^{84}$

\footnotetext{
76 Phillips 2015: 101; Handkerchief Heroes 2015; Hendry 1999: 17-19. Handkerchiefs were used in the North American Ghost Dance as an aid to hypnotism and trance state. Irwin 2008: 261.

77 Davis 1986.

78 Stephens 2014, vol. 2: 206 [ML214 R3f390], 10 November 1846; 228, fn 125 [SLV picture collection H96.

195/17H96. 195/2]; 30 [ML214 R3f206]; Stephens 2014, vol. 1: 10 [ML214 R141], 24 March 1839.

79 Heiss and Minter 2008: 9.

80 Kenny 2008: 38.6.

81 Schaffer 2001:146; Big Black Dog Communication Pty Ltd 2016; Woollacott 2009: 11.1-11.15; Dig: The Burke and Wills Research Gateway 2016.

82 Stephens 2014, vol. 1: 488 [SLV MS14624 Series 1], 24 December 1842.

83 Stephens 2014, vol. 2: 234 [ML214 R3f428], 21 March 1847.

84 Koorie Heritage Trust 2017; University of Melbourne Archives 2017.
} 
In the Moonee Ponds corroboree, the handkerchief acted as a finely crafted container for two significant items of European origin - tobacco and the Christian book - in what were perceived as supernatural or spiritual circumstances. They stood for some of the desired items of Western culture as well as for a symbol of welcome and celebration.

\section{The power of the written word: Letters and books}

Far from a pure technical skill imposed by a Western culture and acting independently on colonised cultures, Peggy van Toorn demonstrates that 'writing never arrives naked'. Aboriginal trade routes took writing and the printed word way beyond the frontier in Australia, incorporating writing into exchange systems, 'using alphabetic signs, paper and books in ways radically different from European norms' ${ }^{85}$ Early on in the Port Phillip Settlement, Aboriginal people become aware of the significance of the letter as a pass or passport to allow them freedom of movement, access to Melbourne and rations and protection from arrest and gaol. ${ }^{86}$ Comparable with the Native American experience, ${ }^{87}$ 'Many of the people were fascinated by the magic of writing and reading and were keen to learn the skills, and to have their children do so' ${ }^{88}$ Thomas referred to requests for letters from him on a number of occasions, ${ }^{89}$ but when an Aboriginal man from the north-west begged a letter from Thomas in order to retrieve his wife, who had been absent two nights, Thomas commented, 'poor fellows they think a letter will almost raise the dead ...'.90

The power of the Christian Bible/Book was often referred to by Thomas in his public and private conversations with the people. On Sunday 12 September 1847, Thomas visited the Northern Encampment on the Yarra and had a serious conversation with the men on 'the importance of being acquainted with God, \& awful state of Man destitute of knowing him'. ${ }^{91}$ He went on to remark upon King Malcolm's son or stepson, who had been incarcerated for some months earlier in the year for severe mental illness:

\footnotetext{
85 Van Toorn 2006: 12. To demonstrate a range of responses to writing, van Toorn uses case studies such as Batman's Treaty and the Coranderrk petitions reflecting cross-cultural use of each other's graphic communication for varying purposes. Writing can be 'reclothed or cross dressed' when similarities in the sound of words has Governor Macquarie renamed as Eaglehawk, the moiety spirit that came to be associated with a superior creator god.

86 Noted also on the Kimberley frontier. Rowse 1987: 89.

87 In the vision of a Delaware Prophet in 1762, the Master of Life gave Neolin a prayer, which was carved into an Indian stick with hieroglyphs. The prophet then produced 'The Great Book of Writing' which was passed and copied from person to person, crossing tribal boundaries. Irwin 2008: 131.

88 Stephens 2014, vol. 1: iv. See also Kenny 2008: 38.9.

89 Stephens 2014, vol. 1: 155 [ML214 R2f93], 18 April 1840; 278 [ML214 R2f526], 30 March 1841; 438 [SLV MS14624 Series 1]; Stephens 2014, vol. 2: 69 [ML214 R3f249], 18 December 1844; 254 [ML214 R3f446], 28 August 1847.

90 Stephens 2014, vol. 2: 95 [ML214 R3f268], 26 March 1845 (emphasis added).

91 Stephens 2014, vol. 2: 264 [ML214 R3f456], 12 September 1847.
} 
I was much struck with Nangkarn. On my addressing them he asked me where was Gods book (I had forgotten to put my prayer book in my pocket ...) I said that I had forgotten it but could do without it, the surprise this black manifested, $\&$ his uneasiness ... he said you tell Black fellow that you know nothing good, do nothing good without Gods book \& now you say you can do without it. ${ }^{92}$

Nangkan had, like seers and spiritual healers in many traditional societies, experienced and recovered from a serious mental illness or challenging supernatural episode. ${ }^{93}$ It is possible that his family link to King Malcolm and episode of madness had given him credibility as a man with peculiar spiritual insight.

Writing was not an independently operating force towards 'civilisation'. It was often clothed with power to give safe passage, effect change or bring useful food and goods. The written word of God in the coloniser's Bible came in richer, spiritual and powerful 'clothing'. The Bible held aloft in the 1851 Moonee Ponds corroboree had appeared under miraculous circumstances and dancers stared at it for 45 minutes. The promise of Mt Cole's King Paget to bring book/s from above the sky in 1852, and the promised change in peace and amity among all people, also marked the power and faith put in this special, magical, written word from the Europeans, a distinct minority of which regularly preached this same truth.

\section{The handshake}

Tiffany Shellam and Penelope Edmonds have alerted us to the significance of handshaking in borders and fringe contact zones as both a physical act of joining hands and as a 'metaphor for friendship and peace'. ${ }^{94}$ Edmonds traces the handshake to Roman times and argues that it is emblematic of the repertoire of British imperialism to effect negotiated compacts, accord and covenants between settler and Indigenous peoples, which at the same time held the seeds of betrayal. ${ }^{95}$ Whether it was an Indigenous practice in the south-west of Western Australia (the focus of Shellam's study) or not, within a few years of intermittent contact with Europeans, as experienced on the American frontier, ${ }^{96}$ it became a shared ritual with subtle changes of meaning and intention understood on both sides, especially when the friendly gesture was denied. ${ }^{97}$

\footnotetext{
92 Stephens 2014, vol. 2: 264 [ML214 R3f456], 12 September 1847.

93 For example, Reid 1983.

94 Shellam 2009: 70.

95 Edmonds 2016: 5, 19-20.

96 Mooney 1973 [1896]: 694-96, 700.

97 Shellam 2009: 70-71. Shellam also notes that as powerful as the gesture was to imply peace, it was also highly likely to have been dangerous to the Aboriginal people, given the transmission of bacteria from coughing and sneezing to a population without immunity. Shellam 2009: 195.
} 
Thomas's journals are liberally peppered with references to shaking hands with Aboriginal people and encouraging them to shake hands with each other. The handshakes are 'cold', 'cordial' or 'enthusiastic', and mean variously 'Welcome'; ${ }^{98}$ 'Farewell', 'Safe journey', 'I mean you no harm'; ${ }^{99}$ or 'I am no longer angry with you' and 'I will argue no more'. ${ }^{100}$ They were initiated as much by Aboriginal as the European population.

It appears that the handshake was customary, or at least modified to suit Wathawurrung culture. An Aboriginal farewell handshake was described by Bunce in Bacchus Marsh, 1849. One by one, in order of closest to least close kin, the men took each other's hand and held it firmly for about five minutes, covering their eyes with their other hand, their heads bent with genuine tears 'oozing through their fingers'. Then with 'two sharp jerks of the hand', they walked off without looking back. ${ }^{101}$

Although Aboriginal people soon keenly participated in the British manner of shaking hands, one can never be really sure whether the meaning of this act was shared by both parties. There were some misunderstandings. Examples in Thomas's journals suggest boisterous, enthusiastic welcome (sometimes mildly threatening and/or instrumental); farewells; secure and not so secure agreements; a perceived charter and agreement to undertake a revenge killing; a wish or compunction to reconcile after an altercation; and a thank you for visiting. ${ }^{102}$

At Mr White's Station (Western Port) in 1840, Thomas was 'followed by groops of Blacks one after the other to Tubbwubabel some ready to pull me off my horse shaking hands' ${ }^{103}$ On a later journey in Western Port the same year, Thomas's party camped with an Aboriginal group on the banks of the Kervan River. 'They were all highly glad to see me shaking hands and asking tobacco at the same time. ${ }^{104}$

\footnotetext{
98 Stephens 2014, vol. 1: 176 [ML214 Rlf148/149], 16 June 1840; 416 [ML214 R2f381], 25 December 1841; 177 [SLV MS14624 Series 4 'Notes and Papers' field notebook], 16 June 1840.

99 Stephens 2014, vol. 1: 334 [ML214 R2f312], 13 July 1841.

100 Stephens 2014, vol. 1: 205-06 [ML214 Rlf190], 2 September 1840; 238 [ML214 R2f190], 18 November 1840; 186 [ML214 Rlf158], 12 July 1840; 507 [SLV MS14624 Series 1], 25 March 1843; Stephens 2014, vol. 2 : 265 [ML214 R3f457], 19 September 1847; 40-41 [ML214 R3f220/221], 24 August 1844.

101 Stephens 2014, vol. 2: 427, fn 221 [The Argus, 7 March 1850: 2]. See also 'Koolin Koolin' ceremony, a ceremonial embrace for those who have been away a long time; Stephens 2014, vol. 1: 514, fn 213 [ML214 Box 3 Item 1/R3f49,WT Journal], 23 September 1840.

102 Stephens 2014, vol. 1: 122 [ML214 R2f32], 10 January 1840; Stephens 2014, vol. 2: 492 [ML214 R4f99], Sunday 11 May 1851; Stephens 2014, vol. 1: 166 [ML214 Rlf144], 22 May 1840; 486 [SLV MS14624 Series 1], 2 September 1842; Stephens 2014, vol. 2: 89 [ML214 R3f263], 24 February 1845.

103 Stephens 2014, vol. 1: 122 [ML214 R2f32], 10 January 1840.

104 Stephens 2014, vol. 1: 177 [SLV MS14624 Series 4], 16 June 1840.
} 
When charged with outrages on the Yarra River in 1840, the Woiwurrung said to Thomas 'that they shook hands with His Honour some time back and \& all gone sulky, there must be some mistake'. ${ }^{105}$ At ration distribution time, 'Capt Turnbull' and Poleorong 'insolently' pointed a finger at Thomas, demanded flour, tea, sugar and rice and insisted on controlling the distribution of flour. They threatened to go to the Governor about it. Thomas was furious and gave them none. 'In the afternoon they come $\&$ beg shake hands, I shake hands but will not give Capt Turnbull.'106

In July 1840, there was a theft of meat and a gun discharged during the night at Thomas's Aboriginal encampment. Thomas was very angry and the person responsible, Young Man Toby, was very anxious to reconcile. His handshake resonates with the traditional more than the introduced.

He rushes to me lays hold of my hand and for some time shook it ... The men was desirous of shaking hands with Toby which I permitted and all seem'd pleased. ${ }^{107}$

When, in 1844, Thomas brought new Aboriginal people from the north-west to the gaol to attempt to translate for a prisoner, he directed these strangers to shake hands with each other and 'I took this opportunity of impressing upon (the prisoner) and the others that all Blacks should be Brothers, like white men'. ${ }^{108}$ After a visit to Melbourne in 1847, Gentleman Jemmy (Yammabook) was taken into custody. Thomas visited him and entreated him to forgive, 'not to be sulky with white people on account of being in custody, but only shake hands \& be good to them' ${ }^{109}$ On this occasion, there is an element of symbolic yielding to the power of the imposed European civilisation.

In 1851, a big gathering of Yarra people near Melbourne resulted in the spearing and later death of McNoal from the encampment. Thomas addressed the encampment for Sunday from Psalm 32:8, 'I will instruct thee \& teach thee in the way which those shall go'. The Aboriginal men 'shook hands with me heartily after service \& vowed vengeance on Quondine' (who had speared McNoal). ${ }^{110}$ The men's interpretation of Thomas's text as support for a vengeance killing was unintended. Thomas tried to reason with them that, as McNoal had appeared to be recovering after the spear wound, his death may have resulted from some cause other than sorcery from enemy tribesmen.

The Aboriginal men and women used the handshake to symbolise apology and reconciliation with Europeans and among each other as well. 'Burreneun goes to Kermitterrewarren and gives him 3 and a half $\mathrm{lb}$ flour and $1 \mathrm{lb}$ sugar as a starting

105 Stephens 2014, vol. 1: 155 [ML214 R2f93], 18 April 1840.

106 Stephens 2014, vol. 1: 163 [ML214 Rlf141], 10 May 1840.

107 Stephens 2014, vol. 1: 184 [ML214 Rlf156], 5 July 1840.

108 Stephens 2014, vol. 2: 38 [ML214 R3f217], 17 August 1844.

109 Stephens 2014, vol. 2: 263 [ML214 R3f455], 3 September 1847.

110 Stephens 2014, vol. 2: 492 [ML214 R4f99], Sunday 11 May 1851. 
position for which he seemed much pleased and shook hands. ${ }^{111}$ Berberry's wife was annoyed with Thomas's wife, Susannah, as the latter had refused to give the former a dress to wear for church and had turned her and her diseased dog out of her house. Later in the day, 'she appeared sorry and shook hands'. ${ }^{12}$

The handshaking involved in the Moonee Ponds corroboree appears to have stood for brotherhood and peace and was thus derivative of European actions and teachings, but it also incorporated new Indigenous aspects, with the touching of the eyes and knees. After some slippages of meaning and misunderstood handshakes in the early years, by the early 1850 s the handshake appeared to have become a strong shared symbol of welcome, friendship, forgiveness, reconciliation and, perhaps at times, enforced submission. ${ }^{113}$ The reconciliatory corroborees, one described as a new Sunday dance, or dance for the Christian Sabbath, drew on the Christianity taught to the mobile groups involved by Protectors such as Thomas in Melbourne and Edward Parker in the Loddon Station, and pious settlers such as Colin Campbell in Mt Cole District. ${ }^{114}$ It also demonstrated engaged creativity and the reinscription of central traditional ritual forms.

\section{Indigenous response to Christianity}

Thomas was sometimes gratified and at other times dissatisfied with his Aboriginal congregations. The members of the congregation in their turn oscillated between derision, indifference and great interest in their responses to Thomas's sermons. ${ }^{115}$ Sometimes the interest was so strong it resembled millenarian fervour. On one occasion, in 1842, Thomas was much encouraged when over 100 attended his service. When he finished, an officer of the Native Police 'begged that he would address another Group whom he thought (them) anxious to hear'. Although Thomas was ill and could not say much, by their excited talk afterwards and almost all of them shaking hands with him, Thomas believed they had felt and understood Christ's words. ${ }^{116}$

\footnotetext{
111 Stephens 2014, vol. 1: 166 [ML214 Rlf144], 22 May 1840.

112 Stephens 2014, vol. 1: 486 [SLV MS14624 Series 1], 2 September 1842.

113 Shellam claims that among the King Yan-up of King George's Sound, Western Australia, it took only two or three years of intermittent, small-scale contact for nuances of this gesture to become understood by both parties. Shellam 2009: 70.

114 Ian Clark, pers. comm., 2015; Ballinger 2013: 15; Quaife 1969.

115 Stephens 2014, vol. 1: 165 [ML214 Rlf148], 14 June 1840; 208 [ML214 Rlf194], 13 September 1840; 212 [ML214 Rlf201], 20 September 1840.

116 Stephens 2014, vol. 1: 476-77 [SLV MS14624 Series 1], 25 September 1842. See van Toorn 2006: 37 for a similar account of the Wiradjeri at Wellington Valley Mission, NSW, in 1836. Distant visitors paid great attention to the Wiradjeri translation of the scriptures, exclaiming in their language, 'Book for blackfellows! Book for blackfellows!'
} 
On other occasions, the Aboriginal men, in particular, said that Thomas's God was not theirs, that they did not fear hell and that he should cease frightening people. ${ }^{117}$ In 1848, Thomas admonished Nerrimbinek for a drunken assault and spoke of hell. Nerrimbinek said, 'he did not care about hell or Death, my Pundgyl was not his Pundgyl'. ${ }^{118}$ When Thomas said that Yanki Yanki (Yonker Yonker) was living a miserable life, 'what is his answer "[If] I like it what's that to white man"'. Yanki Yanki went on to state to Thomas that 'he believed there was a God but did not believe there was a hell or else white man would not get drunk \& swear or they would be afraid of going there'. ${ }^{119}$ A few of the Native Police gathered but 'Beruke begged that I would no speak to them, that blackfellows did not like it it frightened them, I told them that God would punish me when I was dead if I did not tell them what I knew of God \& Christ'. ${ }^{120}$

In 1849, Nerrimbinek was very ill, spitting blood, but refused to take Thomas's medicine. Thomas asked him what he thought God would do to his soul and he answered, 'no me care, go away no you talk to me, like that'. ${ }^{121}$ In 1850 , Thomas commented about how callous and even enraged the Aboriginal people were if you spoke to them about Christianity when 'death appears at hand', 'as tho' the evil one had them more under his power then than any other time'. ${ }^{122}$ Even when God's care of the soul after death was accepted, sorcery remained the explanation for sudden death. ${ }^{123}$

As one who had experienced living with whites and rejected that life when returned to his people, Yonker Yonker was in a position to reflect on the enormity of changes occurring around him. When asked whether he would tell God that Thomas had taught them about God and Christ, he said with conviction: 'We Blackfellows all want a new heart, Your Blackfellow's hearts must be changed.'124

With only limited access to deep knowledge about Aboriginal ontological responses, Thomas's journals give at least a clear indication that the taking on of Christianity was neither uniform nor reflecting gradual, progressive assimilation. The people congregating near Melbourne oscillated or lurched between rejection, acceptance with some theological reservations and, on occasion, excited enthusiasm. The people did not give up searching for solutions for their problems. They met in large groups, talked and talked in meetings, shared experience and knowledge of the new

117 Stephens 2014, vol. 1: 458-59 [SLV MS14624 Series 1], 5 June 1842.

118 Stephens 2014, vol. 2: 305 [ML214 R3f503], 9 April 1848.

119 Stephens 2014, vol. 2: 42 [ML214 R3f222], 30 August 1844.

120 Stephens 2014, vol. 1: 458-59 [SLV MS14624 Series 1], 5 June 1842.

121 Stephens 2014, vol. 2: 403 [ML214 R3f608], 26 August 1849.

122 Stephens 2014, vol. 2: 425 [ML214 R4f12], 6 February 1850.

123 Stephens 2014, vol. 2: 327-28 [ML214 R3f527], 7 September 1848.

124 Stephens 2014, vol. 2: 45 [ML214 Rf225], 15 September 1844. 
white people and, during the 1840 s in particular, in order to survive, they made ritual forays into the new world they were experiencing, searching perhaps for the new heart.

\section{Corroborees and ceremony}

After Thomas began as Assistant Protector in 1839, there were many intertribal gatherings and large discussions in the vicinity of Melbourne as 'tenacious Aboriginal leaders ... used Melbourne as the site of inter-tribal relationships, ceremony and decision-making'. ${ }^{125}$ For example, between October and December 1839, there were eight corroborees near Melbourne noted by Thomas involving Goulburn people as well as Yarra, Western Port and Barabool. Again, in late February to mid-May 1840, there were another 13 referred to, involving most of the same groups: Wathawurrung, Woiwurrung, Bunwurrung, Mt Macedon and Goulburn. Most were associated with corroborees and many with fights or moderated judicial punishments. There were signs of creativity and sometimes millennial thought. In February 1841, when nine Goulburn Aborigines were taken into custody, a 'Celebrated Goulbourn Doctor' prophesised that a 'Cloud of Blood would descend on the District' and the residents from Thomas's station fled. ${ }^{126}$

In June and July 1841, there was a flurry of corroborees, and a couple of initiation, farewell and friendship ceremonies, some performed when there were more than 300 in the camps close to Melbourne. ${ }^{127}$ For a week in September 1842, there were corroborees every night for a week, one involving only women. ${ }^{128}$ On 13 October, 'at noon a Singular' corroboree combined over 400 Goulburn, Yarra and Western Port Aborigines. ${ }^{129}$

On the evening of 22 December 1843 , around 800 people from seven tribes gathered in Melbourne in 'connection with the arrest of two men'. ${ }^{130}$ The ceremonial dance, originating in the Australian Alps, lasted six days and involved seven dances, six of which featured a war emblem and the seventh a bough, the emblem of peace. The dance included 25 pieces of bark to represent each of the new Native Police. The barks were collected together and put in the centre of the camp 'in silence proclaiming

125 Standfield 2012: 10.

126 Stephens 2014, vol. 1: 421, fn 150, PROV VPRS 12 on microfilm VPRS 4467 unit2//PROV VPRS 12/PO unit 4 , bundle 13 , item 91 .

127 Stephens 2014, vol. 1. See also Cahir and Clark 2010.

128 Stephens 2014, vol. 1: 476 [SLV MS 14624 Series 1], 22 September 1842.

129 Stephens 2014, vol. 1: 481 [SLV MS 14624 Series 1], 13 October 1842.

130 Stephens 2014, vol. 1: 571 fn 238 [ML214 Box 3 item 1/R3f57-58]. 
good will to all around'. ${ }^{131}$ Images of Native Police centred on a multitribal force that wreaked some havoc against former enemies and may have been seen as a new centre of Indigenous power.

In April 1845, near to 800 Aboriginal people assembled in Melbourne. ${ }^{132}$ The old chief from north-west of Gippsland reiterated the mountain source of the new corroboree 'conveyed to the Blacks', 'to learn what is good to sing, Gaegape (Gaggip) like white man Sundays church', 'big one Sunday'. Thomas noted the new sacred dances and new curious effigies, altogether new from anything that has yet been heard or seen among the Aborigines of Victoria.. ${ }^{133}$

In 1847, Thomas also took 'copies of the Sacred dance of the Mansfield Blacks', which resonated with biblical tales and psychological loss. A celebrated Dreamer dreamt that all the Aboriginal people were:

together asleep, \& Pundgel was very sulky, \& came down and cut the left arm off, of every man woman $\&$ child. The Interpreters concocted this dance to avoid search taken [?] place, vide rude representation of a figure minus an arm. ${ }^{134}$

Images of amputated people may, like shrinking men in Melanesia, signify loss and powerlessness in the face of British colonialism. ${ }^{135}$

As explained at the beginning of this article, the Vienie Dance was shown to Thomas near Moonee Ponds in 1851. The following day, he found 'much excitement among the people' as they made their preparations to leave. ${ }^{136}$ Then, in March 1852, Thomas described a 'fine Glee Day Dance Flags flying \&c.' on the north bank of the Yarra. Three days later, about 100 people are lying around 'tired after continual exertion in corroborees'. ${ }^{137}$ Much of the innovation in this period was attributed to semi-mythical people in the north-east of Victoria in the Alps. There, celebrated Dreamers, or Clever Men, derived their creative inspiration to modify ritual through dreams.

131 Stephens 2014, vol. 1: 572 fn 240 [ML214 Box 1 item 5/R1f282], Quarterly Report 1 December 1843 to 1 March 1844.

132 Stephens 2014, vol. 2: 78 [ML214 Box 5 R5f7-11] April 1844.

133 Stephens 2014, vol. 2: 95 fn 49 [Paper No. 11 'Superior Races' sent to Duffy on 13 July 1858. Thomas papers R24f90-98].

134 Stephens 2014, vol. 2: 237 [ML214 R3f431], 7 April 1847, 8 April 1847.

135 Clark 1980. See also Fanon 1967.

136 Stephens 2014, vol. 2: 475-76 [ML214 R4f80], 10 January 1851, 12 January 1851; [ML214 R4f81],

13 January 1851.

137 Stephens 2014, vol. 2: 522-23 [ML214 R26f245], 30 March 1852, 2 April 1852. 


\section{Conclusion}

There are many unanswered questions in attempting to elucidate meaning from the corroborees. ${ }^{138}$ The meaning of the human effigies remains obscure while the donkey resonates with Christian imagery. What is apparent is that mimesis created surprise and confusion among European observers and often was appended to an autochthonous framework. There are significant points of comparison and contrast with other settler colony renewal movements.

The dream or visionary source of new dances and rituals and their creative evolution over space and a relatively short time have parallels in North America and New Zealand. The adoption and adaptation of Christian and Western ceremonial objects, and embodied movements in a way that demonstrated internal coherence, further reflected other frontier histories. The mystique of the Bible and the book was common to North American and Australian frontier society, as was adaption of Western ceremonial form and friendship overtures, a desire for peace and, possibly, a change towards gender inclusion for key dance roles. ${ }^{139}$ South-eastern Aboriginal religion already reflected beliefs about an afterlife in the sky, so Christian ideas of heaven were easily transplanted.

Unlike prophet movements in North America and New Zealand, in Victoria large numbers of followers and clear end-point prophesies were not in evidence, with the exception of the Goulburn Doctor predicting a cloud of blood. Victorian Aboriginal people demonstrate neither a rejection of Western material culture nor an obsession with acquiring it. In fact, the Bible, pipe and handkerchief/flags were foregrounded for their symbolic rather than utilitarian value. In contrast to the other settler frontier prophets, there was, at this stage, no complex reworking of biblical scripture to reflect injustice and loss of land and of game. There was, however, a desire for unity, for peace, for happiness and the hope that Bibles, school and traditional ceremonial dances could help in this direction. They appeared to be turning to Christianity rather than contending with it. The two corroborees reflected Indigenous methods of creative change and the re-inscription of a central theme of tribal unity and (Christian) brotherhood of man. The corroborees discussed reflected in a small way the miraculous and hope for transformation on earth but the lead up to them, with corroborees highlighting peace, the place of the

\footnotetext{
138 For example, I have been unable to find references to the Tununderboollook tribe, although 'bulluk' means swamp in the Woiwurrung language and there is a South Australian town called Tanunda, settled in 1842 by Lutheran Prussians, that is a 'long way' (303 miles, 666 kilometres) north-west of Mt Cole, near Beaufort. Similarly, the sender of the sacred dance from the clouds, Veinnee or Vienie, is one of very few words in Thomas's wordlists that begin with 'v', but has some associations with the verb 'to come' and 'old woman' in Latin languages. Thomas's wordlists include vener and venerrer as forms of 'what' or 'which'; verninni, climb up; veamberdun, in; and verring, edible grub. Stephens assumes Vienie refers to a sacred figure akin to Bunjil among the Mt Emu people. Stephens, pers. comm., 2015. 139 An innovative element in Wovoka's Ghost Dance was that males and females had visions at the same time and that both sexes wore feathers. Ostler 2004: 266.
} 
Native Police and dismembered people, gives much stronger evidence that there was a process of autochthonous, creative and innovative effort being expended in the ritual, ontological, epistemological and religious domains, in order to grapple with traumatic change.

The contact zone is a zone where peoples, commodities and cultural ideas mingle, entangle and recombine; where cultural artefacts and patterns are borrowed or created in response to changed circumstances. ${ }^{140}$ The mimesis involved in this process may be elucidated through a focus on specific nodes of contact and performative action with the colonising power through symbolic items and mannerisms. They are embodied without certainty and can operate erratically, but are ultimately a creative response to change with their own coherence, which both embrace and evade incorporation or assimilation with Western institutions. ${ }^{141}$ Thomas's journals remind us that the spiritual must be treated seriously if one is to attain double vision and understanding of meaning in the contact zone.

\section{References}

Ballinger, Robyn 2013, Ararat Rural City Heritage Study Vol 1 Ararat Rural City Thematic Environmental History, History in the Making, Longlea, Victoria.

Berndt, Ronald 1962, An Adjustment Movement in Arnhem Land, Northern Territory of Australia, Mouton, Paris.

Bhabha, Homi 1994, The Location of Culture, Routledge, London.

Big Black Dog Communication Pty Ltd 2016, 'Aboriginal trackers', Australian Government, www.australia.gov.au/about-Australia/australian-story/aboriginaltrackers (accessed 30 December 2015).

Borsboom, Ad 1992, 'Millenarianism, Australian Aborigines and the European myth of primitivism', Canberra Anthropology 15(2): 11-26. doi. org/10.1080/03149099209508448.

Bos, Robert 1988, 'The Dreaming and social change in Arnhem Land', in Aboriginal Australians and Christian Missions: Ethnographic and Historical Studies, Tony Swain and Deborah Rose Bird (eds), Australian Association for the Study of Religions, Bedford Park, South Australia: 422-38.

140 Parker and Rodseth 2005: 3; Penn 2001.

141 Bhabha 1994; Lattas 1998. 
Brady, Maggie 2002, 'Historical and cultural roots of tobacco use among Aboriginal and Torres Strait Islander people', Australian and New Zealand Journal of Public Health 26(2): 116-20. doi.org/10.1111/j.1467-842X.2002.tb00903.x.

Broome, Richard 2005, Aboriginal Victoria: A History since 1800, Allen \& Unwin, Sydney.

-2010, Aboriginal History since 1788, 4th edition, Allen \& Unwin, Sydney.

Byrt, Pauline N. 2004, The Thomas Papers in the Mitchell Library: A Comprehensive Index, Centre for Australian Indigenous Studies, Monash University, Melbourne.

Cahir, David A. and Ian D. Clark 2010, “An edifying spectacle”: A history of “tourist corroborees" in Victoria, 1835-1870', Tourism Management 31: 40220. doi.org/10.1016/j.tourman.2009.04.009.

Cahir, Fred 2012, Black Gold: Aboriginal People on the Goldfields of Victoria 18501870, ANU E Press, Canberra. doi.org/10.26530/OAPEN_459855.

Calley, Malcolm 1965, 'Pentecostalism among the Bandjalang', in Aborigines Now: New Perspectives on the Study of Aboriginal Communities, Marie Reay (ed.), Angus and Robertson, London: 48-58.

Cancer Council of Australia 2016, 'Chapter 8:2: History of tobacco use among Aboriginal peoples and Torres Strait Islanders', in Tobacco in Australia: Facts and Issues, M.M. Scollo and, M.H. Winstanley (eds), www.tobaccoinaustralia.org. au/chapter.8apts/8-2-history-of-tobacco-use-among-aboriginal-people (accessed 20 October 2017).

Christie, Michael 1979, Aborigines in Colonial Victoria 1835-86, Sydney University Press, Sydney.

Clark, Ian D. 1990, Aboriginal Languages and Clans: An Historical Atlas of Western and Central Victoria 1800-1900, Department of Geography and Environmental Science, Monash University, Melbourne.

Clark, Jeffrey 1980, 'The incredible shrinking men: Male ideology and development in Southern Highlands society', Canberra Anthropology 12 (1-2): 120-43.

Courtney, Kris and Ian J. McNiven 1998, 'Clay tobacco pipes from Aboriginal middens on Fraser Island, Queensland', Australian Archaeology 47: 44-53. doi. org/10.1080/03122417.1998.11681607.

Curthoys, Ann 2012, 'Taking liberty: Towards a new political historiography of settler self-government and indigenous activism', in The Atlantic World in the Antipodes: Effects and Transformations since the Eighteenth Century, Kate Fullagar (ed.), Cambridge Scholars Publishing, Newcastle-upon-Tyne, UK. 
Davis, Jack 1986, No Sugar, Currency Press, Sydney.

Dig: The Burke and Wills Research Gateway 2016, burkeandwills.slv.vic.gov.au/ content/terra-incognita/expedition/aborigines (accessed 30 December 2015).

Edmonds, Penelope 2016, Settler Colonialism and (Re)conciliation: Frontier Violence, Affective Performances, and Imaginative Refoundings, Palgrave Macmillan, London. doi.org/10.1057/9781137304544.

Fanon, Franz 1967, Black Skin White Masks, Grove Press, New York.

Fels, Marie Hansen 2011, 'I Succeeded Once, The Aboriginal Protectorate on the Mornington Peninsula 1839-40, Aboriginal History Monograph 22, ANU E Press, Canberra. doi.org/10.26530/OAPEN_459275.

Handkerchief Heroes 2015, handkerchiefheroes.com/ (accessed 20 October 2017).

Heiss, Anita and Peter Minter (eds) 2008, Macquarie PEN Anthology of Aboriginal Literature, Allen \& Unwin, Sydney.

Hendry, Joy 1999, An Introduction to Social Anthropology: Other People's Worlds, Palgrave, New York. doi.org/10.1007/978-1-349-27281-5.

Hogbin, Ian 1958, Social Change, Watts, London.

Irwin, Lee 2008, Coming Down From Above: Prophecy, Resistance and Renewal in Native American Religions, University of Oklahoma Press, Norman.

Jebens, Holger 2004, Cargo, Cult, and Culture Critique, University of Hawai'i Press, Honolulu.

Kenny, Robert 2008, 'Tricks or treat? A case for Kulin knowing in Batman's Treaty', History Australia 5(2): 38.1-38.14.

Koepping, Klaus-Peter 1988, 'Nativistic movements in Aboriginal Australia: Creative adjustment, protest or regeneration of tradition', in Aboriginal Australians and Christian Missions: Ethnographic and Historical Studies, Tony Swain and Deborah Rose Bird (eds), Australian Association for the Study of Religions, Bedford Park, South Australia: 397-411.

Kolig, Erich 1988, 'Mission not accomplished. Christianity in the Kimberleys', in Aboriginal Australians and Christian Missions: Ethnographic and Historical Studies, Tony Swain and Deborah Rose Bird (eds), Australian Association for the Study of Religions, Bedford Park, South Australia: 376-90. 
Koorie Heritage Trust 2017, 'Buckley ran away from ship', Culture Victoria, www. cv.vic.gov.au/stories/aboriginal-culture/the-koorie-heritage-trust-collectionsand-history/buckley-ran-away-from-ship/ (accessed 12 May 2017).

Lattas, Andrew 1998, Cultures of Secrecy, Reinventing Race in Bush Kaliai Cargo Cults, University of Wisconsin Press, Madison.

Lawrence, Peter 1964, Road Belong Cargo, Melbourne University Press, Carlton.

McIntosh, Ian S. 2004, 'Personal names and the negotiation of change: Reconsidering Arnhem Land's Adjustment Movement', Anthropological Forum 14(2): 141-62. doi.org/10.1080/0066467042000238967.

Mead, Margaret 1956, New Lives for Old: Cultural Transformation Manus Island 1928-1953, William Morrow and Co., New York.

Mooney, James 1973 [1896], The Ghost Dance Religion and Wounded Knee, reprinted from 1896, Dover Publications, New York.

Mulvaney, D.J. 1967, 'William Thomas', Australian Dictionary of Biography, National Centre of Biography, The Australian National University, adb.anu.edu. au/biography/Thomas-william-2727, published first in hardcopy 1967 (accessed 25 April 2017).

Nettlebeck, Amanda 2017, 'Colonial protection and the intimacies of Indigenous governance,' History Australia 14(1): 32-47.

Ostler, Jeffrey 2004, The Plains Sioux and U.S. Colonialism from Lewis and Clark to Wounded Knee, Cambridge University Press, Cambridge.

Parker, Bradley J. and Lars Rodseth (eds) 2005, Untaming the Frontier in Anthropology, Archaeology and History, University of Arizona Press, Tucson.

Pascoe, Bruce 2014, 'Foreword', in The Journal of William Thomas Assistant Protector of the Aborigines of Port Phillip and Guardian of the Aborigines of Victoria 1839-1867, Marguerita Stephens (ed.), Victorian Aboriginal Corporation for Languages (VACL), Melbourne, Vols 1 and 2: i-ii.

Penn, Nigel 2001, 'The Northern Cape frontier zone in African frontier historiography', in Colonial Frontiers: Indigenous-European Encounters in Settler Societies, Lynette Russell (ed.), Manchester University Press, Manchester: 19-46.

Petri, Helmut and Gisela Petri-Odeman 1988, 'A nativistic and millenarian movement in north west Australia', trans. Kolig, Erich, in Aboriginal Australians and Christian Missions: Ethnographic and Historical Studies, Tony Swain and Deborah Rose Bird (eds), Australian Association for the Study of Religions, Bedford Park, South Australia: 391-96. 
Phillips, Sandra 2015, 'Literature: Writing ourselves', in From Knowledge of Life: Aboriginal and Torres Strait Islander Australia, Kaye Price (ed.), Cambridge University Press, Cambridge.

Quaife, Geoffrey Robert 1969, 'Colin Campbell 1817-1903', Australian Dictionary of Biography, National Centre of Biography, The Australian National University, adb.anu.edu.au/biography/campbell-colin-3154, published first in hardcopy 1969 (accessed 30 December 2015).

Reed, Liz 2004, 'Rethinking William Thomas, "Friend" of the Aborigines', Aboriginal History 28: 87-99.

Reid, Janice 1983, Sorcerers and Healing Spirits, Australian National University Press, Canberra.

Ripon, Kylie, Fred Cahir and Rani Kerin 2015, 'Faith, belief and religious observance in Australian mining environments', Research Workshop, La Trobe University.

Rosenfeld, Jean E. 1999, The Island Broken in Two Halves: Land and Renewal Movements among the Maori of New Zealand, Pennsylvania State University Press, University Park, PA.

Rowse, Tim 1987, “'Were you ever savages?” Aboriginal insiders and pastoralists' patronage', Oceania 58(1): 81-99. doi.org/10.1002/j.1834-4461.1987. tb02263.x.

Russell, Lynette (ed.) 2001, Colonial Frontiers: Indigenous-European Encounters in Settler Societies, Manchester University Press, Manchester.

2008, 'A New Holland half-caste, sealer and whaler Tommy Chaseland', History Australia 5(1): 8.1-8.15.

Schaffer, Kay 2001, 'Handkerchief diplomacy: E.J. Eyre and sexual politics on the South Australian frontier', in Colonial Frontiers: Indigenous-European Encounters in Settler Societies, Lynette Russell (ed.), Manchester University Press, Manchester.

Scrimgeour, Anne 2006, 'Notions of civilisation and the project to civilise Aborigines in South Australia in the 1840s', History of Education Review 35(1): 35-46. doi. org/10.1108/08198691200600004.

Shellam, Tiffany 2009, Shaking Hands on the Fringe: Negotiating the Aboriginal World at King George's Sound, University of Western Australia Press, Crawley, WA.

Standfield, Rachel 2012, 'Protection, settler politics and Indigenous politics in the work of William Thomas', Journal of Colonialism and Colonial History 13(1): 1-15. doi.org/10.1353/cch.2012.0007. 
Stephens, Marguerita 2014, The Journal of William Thomas Assistant Protector of the Aborigines of Port Phillip and Guardian of the Aborigines of Victoria 1839-1867, 4 vols, Victorian Aboriginal Corporation for Languages (VACL), Melbourne, vols 1 and 2.

Swain, Tony 1993, A Place for Strangers: Towards a History of Australian Aboriginal Being, Cambridge University Press, Cambridge. doi.org/10.1017/ CBO9780511552175.

Swain, Tony and Deborah Bird Rose 1988, 'Introduction: Christian myth adapted to Aboriginal "cosmological" purpose', in Aboriginal Australians and Christian Missions: Ethnographic and Historical Studies, Tony Swain and Deborah Rose Bird (eds), Australian Association for the Study of Religions, Bedford Park, SA: $18-29$.

Thomas, Nicholas 1991, Entangled Objects: Exchange, Material Culture, and Colonialism in the Pacific, Harvard University Press, Cambridge, MA.

Tonkinson, Robert 2004, 'Encounters with the Other: Millenarianism and the permeability of indigenous domains in Melanesia and Australia', in Cargo, Cult and Culture Critique, Helger Jebens (ed.), University of Hawai i Press, Honolulu: $137-54$.

University of Melbourne Archives 2017, "The story of how "corroboree” by Indigenous artist Tommy McRae came to the University of Melbourne Archives', blogs.uni melb.edu.au/archives/the-story-of-how-corroboree-by-indigenous-artist-tommymcrae-came-to-the-university-of-melbourne-archives/ (accessed 12 May 2017).

Van Toorn, Penny 2006, Writing Never Arrives Naked: Early Aboriginal Cultures of Writing in Australia, Aboriginal Studies Press, Canberra.

Watson, Pamela, O. Luanratana and W. Griffin 1983, 'The ethnopharmacology of pituri', Journal of Ethnopharmacology 8: 303-11.

Willis, Elizabeth 2007, 'History, strong stories and new traditions: The case of "Etched on bark 1854"', History Australia 4(1): 13.1-13.11.

Woollacott, Angela 2009, 'Frontier violence and settler manhood', History Australia 6(1): 11.1-11.15.

Worsley, Peter 1957, The Trumpet Shall Sound: A Study of Cargo Cults in Melanesia, Paladin, London. 
This text is taken from Aboriginal History, Volume 41, 2017, edited by Ingereth Macfarlane, published 2017 by ANU Press, The Australian National University, Canberra, Australia.

dx.doi.org/10.22459/AH.41.2017.06 